\title{
Rekonstruksi Pemahaman Berkat Berdasarkan Tafsiran Kejadian 12:1-3 Di Gereja Toraja Jemaat Kollo Klasis Tondon
}

\author{
Mordica \\ Institut Agama Kristen Negeri (IAKN) Toraja \\ mordica123@yahoo.com
}

\begin{abstract}
Blessing is the most important part of life of christians, expecially in Gereja Toraja Jemaat Kollo Klasis Tondon. Many people assume that Lord's blessing is just a good things, while the distress, suffering, and other disaster is not a blessing of the Lord. This comprehension also developing in church members of Jemaat Kollo Klasis Tondon. This is inspiring the writer to do research, how theology of Lord's blessing in Genesis 12:1-3 and how the comprehension that should be owned by church members of Jemaat Kollo Klasis Tondon about Lord's blessing. The purpose of this study is to know the theology of Lord's blessing according to the Holy Bible in Genesis 12:1-3 and the comprehension that should be owned by church members based on exegesis Genesis 12:1-3. Writer use historical analysis and background analysis as well as text analysis, and expalin how comprehension of the church member about Lord's blessing and how the comprehension that should be owned by church members based on exegesis Genesis 12:1-3 with using a qualitative research and study fieldwork.
\end{abstract}

\section{Keywords: Blessing, Torajan Church, Genesis 12, Old Testament}

\begin{abstract}
Abstrak: Berkat merupakan bagian terpenting dalam kehidupan setiap orang Kristen seperti di Jemaat Kollo Klasis Tondon. Banyak orang percaya beranggapan bahwa berkat Tuhan hanyalah hal yang baik-baik saja, sedangkan kesusahan, penderitaan, dan bencana lainnya dipandang bukan berkat daripada Tuhan. Pemahaman ini juga berkembang di kalangan anggota Jemaat. Penulis melakukan penelitian tentang teologi berkat dalam Kejadian 12:1-3 dan bagaimana pemahaman yang seharusnya dimiliki oleh anggota. Tujuan dari tulisan ini adalah untuk mengetahui teologi berkat menurut Kejadian 12:1-3 dan pemahaman yang seharusnya dimiliki warga Jemaat tentang berkat Allah. Penulis menggunakan pendekatan analisis sejarah dan latar belakang, serta analisis teks dan memaparkan bagaimana pemahaman anggota Jemaat tentang berkat dan bagaimana seharusnya pemahaman yang dimiliki oleh anggota Jemaat berdasarkan tafsiran Kejadian 12:1-3 dengan menggunakan metode kualitatif melalui studi lapangan.
\end{abstract}

Kata Kunci: Berkat, Gereja Toraja, Kejadian 12, Perjanjian Lama

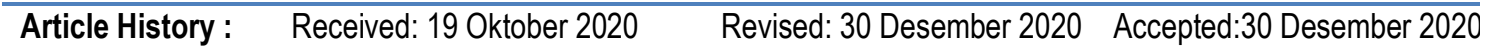




\section{Pendahuluan}

Orang Kristen beranggapan bahwa berkat adalah segala hal yang baik yang terjadi dalam kehidupan ini. Ketika berbicara tentang berkat, orang akan menceritakan segala hal yang baik yang diterima dan dialami dalam hidup sedangkan hal buruk sering dipandang sebagai suatu kutukan atau hukuman. Kutuk selalu dipandang sebagai penderitaan yang menyengsarakan seperti penyakit, kesusahan, bencana, dan kemiskinan.

Ketika berdoa, orang Kristen seringkali berkata: "Tuhan berkatilah hidup kami”. Ketika berkata demikian, maka yang muncul dalam pikiran ialah berkat kesehatan, kekayaan/meteri, kebahagiaan, keturunan, dan hal lainnya yang dipandang baik. Tak pernah terlintas di pikiran ketika meminta berkat, Tuhan akan memberikan sakitpenyakit, kesusahan, penderitaan yang dipandang tidak baik. Ketika merasa bahwa Tuhan telah mendengar doa dengan adanya sesuatu yang dianggap baik sedang terjadi dalam hidup, maka langsung disimpulkan Tuhan sedang memberi berkat. Namun, ketika terjadi hal yang tidak sesuai dengan harapan atau keinginan, itu dianggap bukan berkat tapi teguran dari Tuhan atau bahkan seringkali disebut sebagai kutukan. Pemikiran seperti itu juga berkembang dalam kehidupan warga Gereja Toraja Jemaat Kollo Klasis Tondon. Pandangan mereka tentang berkat Tuhan tak jauh berbeda dengan orang Kristen pada umumnya. Mereka sependapat dengan pernyataan bahwa berkat adalah hal yang mendatangkan sukacita, damai, kebahagiaan, dan segala hal yang baik. Beberapa warga jemaat Kollo mengatakan bahwa berkat itu seperti pekerjaan, harta benda, keturunan, umur panjang, dan hal-hal baik lainnya. Sedangkan hal-hal yang membuat kita susah salah satunya seperti sakit penyakit bukan berkat dari Tuhan melainkan teguran dari Tuhan. Pemikiran seperti itu ada karena melihat berkat Tuhan sebagai suatu perbandingan kemakmuran dan kepuasan diri dalam hidup.

Dari pandangan orang Kristen secara umum maupun warga jemaat Kollo tentang berkat adalah suatu hal yang terjadi yang mendatangkan kebaikan atau kebahagiaan memunculkan pertanyaan benarkah berkat itu adalah sesuatu yang baik-baik saja? Apakah hal yang tak baik atau buruk dalam hidup bukan berkat? Ketika penderitaan datang dalam hidup, penyakit yang tak kunjung sembuh, harta kekayaan tidak ada dan hidup penuh dengan kesusahan, apakah ini adalah kutukan dan bukan berkat dari Tuhan? Benarkah bahwa berkat hanyalah sesuatu yang baik-baik saja? Oleh sebab itu, hal ini penting untuk dikaji lebih lanjut karena berkat dalam hidup orang Kristen secara khusus bagi warga jemaat Kollo Klasis Tondon dipandang sangat penting dan berhubungan dengan iman. Orang akan bersyukur ketika diberkati dengan konsep pemikiran seperti yang telah dijelaskan di atas dan akan bersungut-sungut ketika mereka merasa tidak diberkati. Jemaat perlu memahami arti berkat Tuhan yang sesungguhnya. 


\section{Metode Penelitian}

Penelitian ini merupakan kajian eksegese Kejadian 12:1-3 tentang berkat. Hasil kajian eksegese tersebut selanjutnya akan diteliti implementasinya dalam kehidupan berjemaat di Jemaat Kollo. Pendekatan tafsiran yang digunakan terhadap Kejadian 12:13 adalah analisis sejarah dan latar belakang, serta analisis teks. Dan metode penelitian yang digunakan adalah jenis penelitian kualitatif, melalui studi pustaka dan studi lapangan.

\section{Hasil dan Pembahasan}

\section{Latar Belakang Historis Kejadian 12: 1-3}

Nama Abram berarti 'bapa yang tinggi' atau 'bapa yang agung', tetapi pada usia 99 tahun, Allah mengganti namanya menjadi Abraham yang berarti 'bapa orang banyak' atau 'bapa sejumlah besar bangsa' (Kej. 17:5), hal ini menyiratkan bahwa Abraham telah menjadi tokoh utama yang baru dalam penyelenggaraan sejarah penebusan dari Allah. Abram adalah bapa pertama umat manusia, Nuh menjadi bapa umat manusia dari dunia baru setelah Air Bah, dan Abraham adalah bapa dari umat pilihan, Israel. Abraham juga adalah bapa dari umat pilihan yaitu Israel dan bapa iman dari umat segala bangsa di dunia di dalam Yesus Kristus. ${ }^{1}$

Abraham pertama kali dipanggil oleh Allah yang Mahamulia di Ur-Kasdim. Asal kata אוּר (Ur) berarti terang atau api. Para ahli berpendapat bahwa kata ini berasal dari upacara penyembahan berhala ketika orang-orang menyembah api di zaman itu. ${ }^{2}$ Asal kata ini menunjukkan bahwa Abraham hidup di zaman yang sepenuhnya jatuh ke dalam dosa dan yang penuh dengan penyembahan berhala. Yosua juga berkata kepada umat Israel di Yosua 24:2, “... Dahulu kala di seberang Sungai Efrat, di situlah diam nenek moyangmu, yakni Terah, ayah Abraham dan ayah Nahor, dan mereka beribadah kepada allah lain." Suatu hari, Allah yang Mahamulia menampakkan diri-Nya kepada Abraham dan memerintahkannya untuk meninggalkan Ur-Kasdim (Kis 7:2-3). Jadi, Abraham mengikuti ayahnya, Terah, meninggalakan Ur-Kasdim dan menetap di Haran (Kej. 11:31). ${ }^{3}$ Haran adalah satu dari kota-kota Padan-Aram di wilayah utara Mesopotamia dan kota tersebut sangat indah. Diduga bahwa sejumlah besar keluarga dan kerabat dari garis keturunan Sem hidup di sekitar wilayah ini (Kej. 10:22, 24:4, 25:20, 28:5). Setelah Abraham meninggalkan Ur-Kasdim, Abraham menetap di Haran. Terah dilahirkan di dalam suasana dosa dan kejahatan nenek moyangnya, dibesarkan serta makan dan minum di dalam suasana dosa dan kejahatan. Karena kebiasaan berbuat dosa telah mendarah daging, Terah tidak dapat memutuskan ikatan perbuatan dosa dan kejahatan, sehingga dia ingin tetap tinggal di Haran, tempat persinggahan di tengah perjalanan. Abraham telah menetap cukup lama bersama dengan Terah di Haran ketika Abraham

${ }^{1}$ Abraham Park, Seri 1 Sejarah Penebusan: Silsilah Di Kitab Kejadian (Jakarta: Gramedia Widiasarana Indonesia, 2010), 202.

2 Ibid, 203.

${ }^{3}$ Ibid. 
menerima panggilan kedua dari Allah. Pada usia 75 tahun, Abraham meninggalkan Haran sebab Allah memberi perintah di Kejadian 12:1, "Pergilah dari negerimu dan dari sanak saudaramu dan dari rumah bapamu ini ke negeri yang akan Kutunjukkan kepadamu." 4 Dari situlah awal mula Allah mendeklarasikan perjanjian-Nya kepada Abraham, perjanjian yang terjadi atas dasar kedaulatan Allah.

Perjanjian Allah dengan Abraham merupakan perjanjian yang tidak bersyarat. Panggilan Allah kepada Abraham yang bertumbuh di dalam keluarga pagan yang menyembah berhala, bukan hanya sekedar penggilan dan penyelamatan terhadap seseorang. Panggilan ini mempunyai arti yang sangat penting bahwa Allah menjadikannya sebagai bapa iman dan memulai keberangkatan baru untuk penebusan umat manusia. ${ }^{5}$ Perjanjian Allah dengan Abraham merupakan perjanjian dengan kasih karunia kedaulatan-Nya untuk mewujudkan janji yang diberikan kepada Adam. Lalu, Dia merencanakan untuk memberikan berkat kepada segala bangsa lewat Abraham dan meratifikasi sebuah perjanjian. ${ }^{6}$ Ini berarti bahwa perjanjian Allah dengan Abraham merupakan perjanjian yang dibaharui dari perjanjian Allah dengan Adam. Abraham menempati tempat utama di dalam klimaks pernyataan Allah. Mengapa? Karena Abraham merupakan orang yang dipilih langsung oleh Allah dan kepada Abrahamlah Allah memberikan hak istimewa. Hak istimewa itu ialah Abraham diberkati oleh Allah dan akan menjadi berkat (Kej. 12:2), dan olehnya Allah akan memberkati seluruh bangsa (Kej. 12:3).

\section{Struktur Kejadian 12:1-3}

Ayat 1 : Pemanggilan Abraham

Ayat 2-3 : Berkat Tuhan kepada Abraham

\section{Tafsiran Kejadian 12:1-3}

Ayat 1: Pemanggilan Abraham

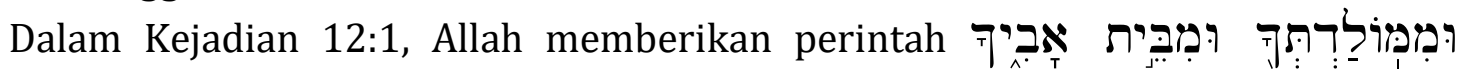

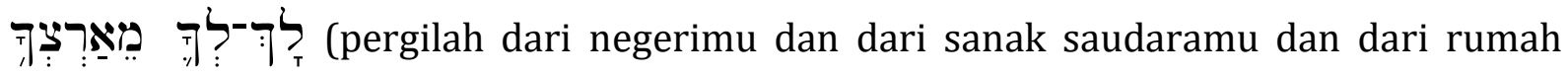
bapamu ini) kepada Abraham. Abraham menerima perintah dari Tuhan untuk meningalkan negerinya, tempat kelahirannya. Perintah ini merupakan ujian apakah Abraham mencintai tanah kelahirannya dan teman-temannya, dan apakah Abraham bisa meninggalkan semuanya dengan rela, untuk pergi mengikuti Allah. ${ }^{7}$ Ketika Tuhan memberikan janji itu, negerinya sudah jatuh dalam penyembahan berhala. Ayah dan sanak saudaranya juga ikut dalam penyembahan berhala itu. Inilah salah satu maksud Allah memanggil Abraham untuk keluar dari penyembahan berhala yang telah mendarah daging dalam keluarga dan sanak saudaranya.

\footnotetext{
${ }^{4}$ Abraham Park, Seri 1 Sejarah Penebusan: Silsilah Di Kitab Kejadian (Jakarta: Gramedia Widiasarana Indonesia, 2010), 203.

${ }^{5}$ Abraham Park, Seri 2 Sejarah Penebusan: Pertemuan Yang Terlupakan; Perjanjian Suluh dan Penggenapannya (Jakarta: Gramedia Widiasarana Indonesia, 2011), 91

${ }^{6}$ Park, Seri 1 Sejarah Penebusan: Silsilah Di Kitab Kejadian, 203.

${ }^{7}$ Matthew Henry, Kitab Kejadian (Surabaya: Momentum, 2014), 286-287.
} 
Meredith G Kline menafsirkan perintah itu dengan pendapat bahwa penyembahan keluarga Terah kepada berhala harus ditinggalkan dan ketaatan harus dipersembahkan kepada Tuhan. ${ }^{8}$ Abraham harus menyerahkan hidupnya seluruhnya hanya ke dalam tangan Tuhan sebab Tuhanlah yang telah memanggilnya untuk pergi dari negerinya dan meninggalkan penyembahan berhala yang dilakukan keluarganya. Panggilan Abraham tidak hanya terdiri atas berbagai janji, tetapi juga atas berbagai kewajiban. Allah menuntut baik ketaatan maupun penyerahan pribadi kepada-Nya sebagai Tuhan agar dapat menerima apa yang dijanjikan. Iman dan ketaatan kepada Tuhan merupakan suatu kewajiban yang harus dimiliki oleh Abraham. Ketaatan dan kepercayaan itu seperti kepercayaan kepada Firman Allah, sekalipun realisasi janji-janji tersebut kelihatan mustahil secara akal manusia (Kej 15:1-6; 18:10-14), ketaatan kepada perintah Allah untuk meninggalkan tempat tinggalnya (Kej 12:4; Ibr 11:8) dan usaha yang sungguh-sungguh untuk menjalankan hidup yang benar (Kej 17:1-2). ${ }^{9}$ Hal itu menjadi kunci dalam pemanggilan Abraham untuk penggenapan janji berkat Tuhan kepadanya.

Dengan perintah ini juga Abraham diuji apakah Abraham dapat mempercayai Tuhan lebih jauh daripada yang dilihatnya,sebab Abraham harus meninggalkan nergerinya sendiri, untuk pergi ke negeri yang akan ditunjukkan Tuhan kepadanya.

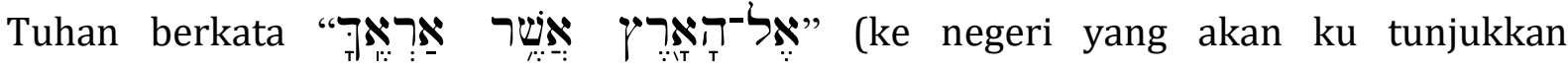
kepadamu). Tuhan tidak berkata, "Itu adalah sebuah negeri yang akan Kuberikan kepadamu," melainkan hanya, "sebuah negeri yang akan Kutunjukkan kepadamu." Tuhan juga tidak memberi tahu kepadanya negeri itu, atau seperti apa negeri itu. Abraham hanya harus mengikuti Tuhan dengan iman semata dan percaya saja pada apa yang dikatakan-Nya dalam hal ini, secara umum, meskipun Abraham tidak diberi jaminan khusus bahwa Abraham tidak akan rugi meninggalkan negerinya untuk mengikuti Tuhan. ${ }^{10}$ Abraham tidak diberitahu tujuannya, sehingga dapat mengambil keputusan, menurut baik-jeleknya negeri yang baru itu. Tetapi Abraham diundang mempercayai Tuhan yang telah memanggilnya (Kej 15:6), bahwa tawaran Tuhan bukanlah omong-kosong atau kabar-angin saja. Tuhan menjanjikan negeri yang baru: kapan, dimana dan dengan apa Abraham diikat kepada kesetiaan Tuhan yang tidak kelihatan (Ibr 11:1, 8-12).11 Abraham pergi dengan keyakinan akan janji Tuhan meskipun tidak mengetahui dimana dan bagaimana negeri yang akan ditunjukkan Tuhan kepadanya. Iman yang dimiliki oleh Abraham akan menuntunnya hingga sampai pada janji berkat yang Tuhan berikan kepadanya.

Ayat 2-3: Berkat Tuhan kepada Abraham

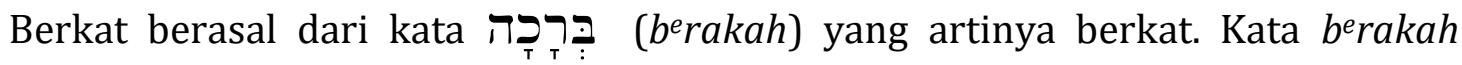
biasanya dalam konteks Alkitab merupakan suatu tindakan dari yang tertinggi

\footnotetext{
1998), 100.

${ }^{8}$ A. Simanjuntak, dkk, Tafsiran Alkitab Masa Kini 1 (Jakarta: Yayasan Komunikasi Bina Kasih/OMF,

${ }^{9}$ Lembaga Alkitab Indonesia - Penerbit Gandum Mas, The Full Life Study Bible: Alkitab Penuntun Hidup Berkelimpahan (Malang: Gandum Mas dan LAI, 2015), 25.

${ }^{10}$ Henry, Kitab Kejadian, 287-288.

11 Walter Lempp, Tafsiran Alkitab: Kitab Kejadian 5:1-12:3 (Jakarta: BPK Gunung Mulia, 2009), 201.
} 
kedudukan atau posisinya kepada yang rendah atau bawahannya. Dalam Alkitab, berkat tentu dari Tuhan kepada manusia atau tepatnya dari Tuhan kepada umat-Nya. Umumnya dalam bentuk ucapan atau firman. Dalam konteks Alkitab, ini berarti suatu bentuk penyataan atau pewahyuan dari Tuhan kepada umat-Nya tentang berkat, keuntungan, kenyamanan, dan damai. Dan ucapan tersebut dinyatakan dalam sebuah aksi yang nyata. ${ }^{12}$ Tuhan menunjukkan kasih dan kedaulatan-Nya kepada umat-Nya melalui berkat yang Dia berikan.

Dalam Kejadian 12:2, Tuhan menjanjikan berkat kepada Abraham. Pertama-tama

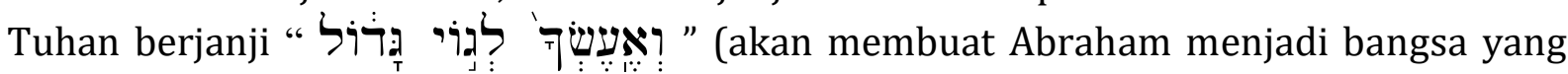

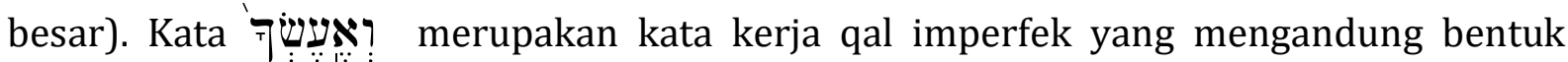
kohortatif. Bentuk imperatif hanya dipakai untuk mengungkapkan perintah positif dan tidak pernah mengungkapkan sebuah larangan. Qal imperatif dapat dijelaskan sebagai bentuk pendek dari qal impefek. ${ }^{13}$ Bentuk kohortatif artinya menyatakan suatu keinginan, kemauan dan tekad bulat dari orang yang sedang berbicara (orang 1 tunggal).14 Dengan demikian, kata Tuhan untuk menjadikan Abraham sebagai bangsa yang besar. Selanjutnya, Tuhan

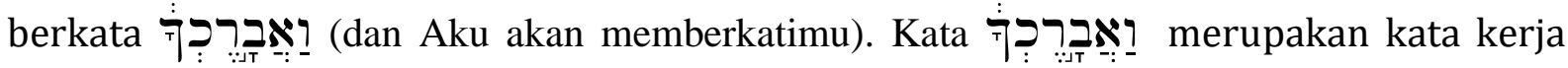
piel imperfek dari kata dasar ברך yang artinya "memberkati". Konyugasi Piel seringkali mempertegas arti kata kerja. Piel menggambarkan suatu tindakan yang dilakukan dengan lebih tegas atau secara berulang-ulang. ${ }^{15}$ Konyugasi piel selalu mempunyai arti aktif. ${ }^{16}$ Dengan demikian maka kata terus berlangsung untuk selama-lamanya. Tuhan memberikan janji berkat kepada Abraham dengan tindakan aktif yaitu akan terus memberkati Abraham. Bentuk keaktifan Tuhan dalam janji yang diberikan kepada Abraham terlihat dari firman Tuhan

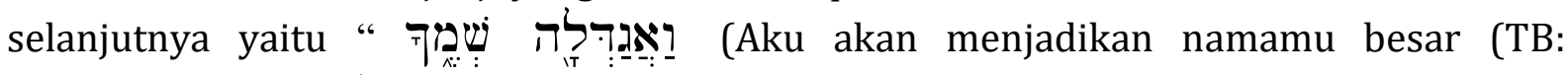

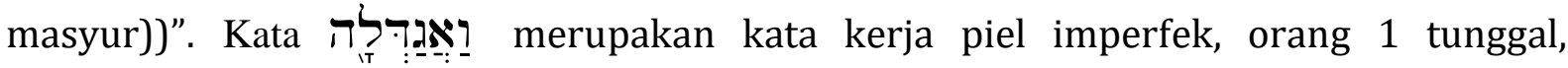
kohortatif. Tuhan menyatakan tindakan aktifnya melalui kemauan atau keinginan-Nya untuk memberi kebesaran nama atau kemasyuran nama kepada Abraham. Namun halhal tersebut tidak langsung terjadi begitu saja dalam kehidupan Abraham. Banyak hal yang harus dikorbankan oleh Abraham untuk menerima semua itu. Ketika Abraham dipanggil oleh Allah untuk pergi dari negerinya, ia adalah orang yang isterinya mandul, yang tidak punya harapan lagi akan keturunan, tetapi dijanjikan keturunan yang besar oleh Tuhan. Abraham meninggalkan negerinya tanpa berpikir panjang dan tawar menawar dengan Tuhan. Abraham pergi dengan sukacita tanpa bertanya-tanya karena kepercayaannya kepada Tuhan. Yang ditinggalkannya (sanak saudaranya) diberi Allah

${ }^{12}$ I. Ketut Enoh, "Tinjauan Teologis Tentang Arti Berkat Dalam Kehidupan Orang Percaya”, Jaffray, Vol 10, No. 1 Tahun 2012, 152.

${ }_{13}$ Page H. Kelley, Pengantar Tata Bahasa Ibrani Biblika (Surabaya: Momentum, 2013), 179.

14 T.G.R. Boeker, Bahasa Ibrani Jilid II (Batu: Literatur YPPII, 1993), 9.

$15 \mathrm{Ibid}, 45$.

${ }^{16}$ D.L. Baker, S.M. Siahaan, dan A. A. Sitompul, Pengantar Bahasa Ibrani (Jakarta: Gunung Mulia, 2010), 167. 
kepadanya secara baru (keturunannya). Dalam Perjanjian Lama isi berkat Allah sangat dekat berhubungan dengan keturunan (bnd. Kej 1:22,28). Hal ini pun nyata bagi Abraham dilihat dari silsilah keturunan Abraham. ${ }^{17}$ Keturunan merupakan suatu hal yang dipandang penting dalam dunia Perjanjian Lama. Abraham pun juga pada akhirnya memiliki keturunan yang banyak, yang tak terhitung jumlahnya seperti yang dijanjikan oleh Allah (Kej. 15:5).

Tuhan membentengi Abraham secara kokoh dengan janji-janji berupa kemakmuran, banyak keturunan dan kemasyhuran. Janji akan berkat ilahi memberikan kepada Abraham jaminan bahwa ia dapat memperoleh segala sesuatu yang ia inginkan. Setiap kebutuhannya akan dipenuhi. ${ }^{18}$ Berkat dalam Perjanjian Lama berarti bermacammacam pertambahan kehidupan, pergandaan penghidupan. Barangkali kata berkat yang pertama dalam ayat 2 dapat dipahami sebagai harta benda Abraham (Kej. 13:2: "Adapun Abram sangat kaya, banyak ternak, perak dan emasnya"). Tetapi kata berkat kedua (ay.

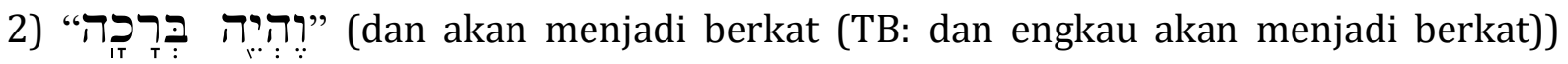
dengan segera membatasi pengertian pertama itu. Kata רִ: merupakan kata kerja qal imperative yang meiliki makna suatu perintah dari Tuhan kepada Abraham untuk menjadi berkat. Tindakan aktif Allah tidak hanya dinyatakan kepada Abraham tetapi kepada bangsa yang lain. Melalui Abraham, Tuhan memberikan berkat-Nya kepada bangsa lain. Abraham diberkati oleh Tuhan untuk menjadi berkat. Abraham bukan hanya menerima apa-apa (sesuatu berkat), melainkan Abraham dijadikan berkat. Dengan ini pengertian berkat sebagai harta saja dibatalkan: Abraham bukan hanya menerima apa-apa, melainkan Abraham diubah menjadi orang baru: pembawa kehidupan, pemikul keselamatan, pembuat perdamaian, pemberi sejahtera dan keamanan, pembina kebenaran dan keadilan, dan pendiri ibadat yang tulen. ${ }^{19}$ Dalam kata berkat terkandung keselamatan yang terakhir dan tertinggi, yang diberi Allah kepada manusia. ${ }^{20}$ Bahkan orang-orang di sekitarnya yang memusuhinya akan memandang kepadanya sebagai pemimpin umat Allah. Melalui dia semua bangsa di bumi akan diberkati. Namanya akan dihormati sebagai "bapa" oleh orang Kristen, orang Yahudi dan orang Islam. Allah memilih Abraham dan keturunannya untuk memberitakan Injil-Nya ke seluruh dunia. Dari keturunan Abraham akan datang Kristus untuk menggenapi maksud-maksud Allah. Dan melalui orang-orang yang "telah dilahirkan baru" segala rencana-Nya akan digenapi. Rencana Allah mulai tampak bentuknya. ${ }^{21}$ Walter Lempp mengatakan bahwa di dalam Abraham segala macam manusia akan mengenali dan mengakui berkat dan keselamatan yang dari Allah, Tuhan semesta alam dan banyak orang akan menerima baik dan menyambut Abraham sebagai pembawa berkat (keselamatan). Mereka semuanya akan menerima bagian dan warisan berkat yang sama dengan yang dipunyai Abraham. Keselamatan yang dari Allah tidaklah terbatas, melainkan universal, ditujukan kepada seluruh manusia, kepada seisi dunia,

\footnotetext{
17 Lempp, Tafsiran Alkitab: Kitab Kejadian 5:1-12:3, 201.

18 Pfeiffer dan Harrison, The Wyclife Bible Commentary: Tafsiran Alkitab Wyclife Volume 1, terjemahan Hananiel Nugroho, dkk, 63-64.

${ }^{19}$ Lempp, Tafsiran Alkitab: Kitab Kejadian 5:1-12:3, 201.

20 Ibid.

21 Pfeiffer dan Harrison, The Wyclife Bible Commentary: Tafsiran Alkitab Wyclife Volume 1 Terjemahan Hananiel Nugroho, dkk, 63-64.
} 
dengan perantaraan Abraham. ${ }^{22}$ Berkat Tuhan dalam hal ini diberikan kepada semua umat manusia yang percaya kepada Tuhan yang disembah oleh Abraham.

Perjanjian Allah kepada Abraham tidak hanya dinyatakan dalam bentuk perintah supaya Abraham meninggalkan negerinya, sanak saudaranya dan rumah bapanya menuju tempat yang akan Allah tunjukkan kepadanya (Kej. 12:1), namun Allah mengikat Abraham dengan perjanjian-Nya dalam Kejadain 12:2-3. Tentang hal ini, John F. Walvoord dan Roy B. Zuck menyatakan bahwa panggilan Abraham memiliki tujuan, yakni ketaatannya akan membawa berkat yang besar. Jika Abraham keluar dari Ur, Tuhan akan melakukan tiga hal untuknya, sehingga ia kemudian bisa menjadi berkat di tanah yang akan ditunjukkan kepadanya. Tiga janji yang berdasarkan panggilan Allah bagi Abraham untuk meninggalkan negerinya: (a) suatu bangsa yang besar, (b) berkat bagi Abraham, dan (c) namanya mashur (ayat 2). Ditambahkan lagi, Abraham harus menjadi berkat sehingga Allah akan melakukan tiga hal lain yang seimbang dengannya, yakni Allah akan: (a) memberkati orang-orang yang memberkatinya, (b) mengutuk siapa saja yang akan memperlakukan dia ringan, dan (c) memberkati keluarga di bumi melalui dia (ayat 3 ). ${ }^{23}$

Ayat 3 menunjukkan bahwa perlindungan Tuhan bagi Abraham adalah sempurna. Janji dalam ayat 3 membuat Tuhan dan Abraham seperti membentuk semacam tim, baik untuk menyerang maupun bertahan. ${ }^{24}$ Walter Lempp menafsirkan bahwa barangsiapa yang berjumpa, yang berhadapan dengan Abraham tidak boleh tinggal seperti dahulu melainkan harus menentukan sikapnya terhadap Abraham, terhadap keselamatan (kesejahteraan) yang dari Allah. ${ }^{25}$ Melalui Abraham, semua kaum akan mengenal Allah, Tuhan semesta alam dan mengakui berkat dan keselamatan yang dari Allah. Dan banyak orang akan menerima baik dan menyambut Abraham sebagai pembawa berkat (keselamatan). Mereka semua akan menerima bagian dan warisan berkat yang sama dengan yang dipunyai Abraham. Itulah yang Tuhan katakan bahwa Tuhan akan memberkati orang yang memberkati Abraham. Begitupun sebaliknya, barangsiapa yang mengutuk Abraham akan dikutuk oleh Tuhan. Bukan semua orang akan memberkati (menerima baik) Abraham. Bukan seluruh manusia akan menerima keselamatan yang dikerjakan oleh Allah, melainkan menolak sekuat-kuatnya kehendak Allah untuk menyelamatkan manusia. Bahkan sejumlah manusia akan melawan dengan hebat (mengutuk) dan tidak mengambil-alih jalan keselamatan yang dari Allah, yaitu dengan tidak mengikuti Abraham dan tidak mau dipengaruhi olehnya (bnd. Kis 16:20 21). Mereka menganggap Abraham sebagai penggangu dan pengacau dalam kebiasaan mereka dalam adat mereka sendiri. Sebab itu, mereka mengutuk Abraham. Orang seperti itu bukan hanya tidak menerima berkat Tuhan melainkan dikenai hukuman dari Tuhan atau dikutuk Tuhan. ${ }^{26}$ Allah menjadi benteng dan perlindungan yang sangat sempurna bagi Abraham sesuai dengan perjanjian yang dibuat Allah untuk Abraham.

${ }^{22}$ Lempp, Tafsiran Alkitab: Kitab Kejadian 5:1-12:3, 202.

${ }^{23}$ Widianto, "Sifat Panggilan Allah: Studi terhadap Panggilan Allah kepada Abraham dalam Kejadian 12:1-4", 4.

${ }^{24}$ Henry, Kitab Kejadian, 290.

${ }^{25}$ Lempp, Tafsiran Alkitab: Kitab Kejadian 5:1-12:3, 202.

${ }^{26}$ Lempp, Tafsiran Alkitab: Kitab Kejadian 5:1-12:3, 202-203. 


\section{Teologi Perjanjian Berkat menurut Kejadian 12:1-3}

Kejadian 12 mengisahkan tentang pemanggilan Abraham yang disertai dengan pemberian janji berkat Allah kepada Abraham. Allah memanggil Abraham untuk pergi dari negerinya, dan keturunannya, dan dari rumah bapanya ke negeri yang akan Tuhan tunjukkan kepadanya. Tentu ini bukan perkara mudah bagi Abraham untuk memilih tetap tinggal bersama dengan keluarganya di negerinya atau memilih untuk pergi ke negeri yang Tuhan akan tunjukkan kepadanya yang sama sekali belum jelas dimana dan seperti apa negeri itu. Ini merupakan awalan baru dalam kehidupan Abraham sekaligus tantangan iman bagi Abraham. Banyak yang diminta Allah dari Abraham: ia harus meninggalkan negeri dan sanak saudaranya, memisahkan diri dari semua yang cinta kepadanya dan yang dapat melindungi dia, dan hanya menyerahkan diri kepada Allah. Abraham harus ber-"hijrah", seperti yang disebutkan orang Arab yang berarti memutuskan perhubungan dengan orang-orang sekaumnya. Abraham tidak boleh mencari perlindungan manusia, ia hanya boleh percaya kepada kekuasaan Allah. Pada zaman Abraham belum ada pemerintahan yang melindungi jiwa dan milik manusia, seperti pada zaman sekarang ini; kaum-keluargalah yang membelanya dan melindunginya; tetapi sekarang Abraham tidak tahu ke mana ia akan bertolak, ia harus pergi ke negeri yang akan ditunjukkan Allah kepadanya. ${ }^{27}$ Semua ini hanya dapat dilakukan Abraham oleh karena imannya kepada Allah. Iman dan ketaatannya membawa Abraham pergi dari negerinya dengan mempercayakan hidupnya hanya kepada Allah yang telah memanggilnya. Oleh karena iman dan ketaatan Abraham, Allah memperhatikan dan memberkatinya. Allah memberkatinya dan menjadikannya berkat bagi bangsa/orang lain.

Dalam menjalani panggilan Tuhan, Abraham menghadapai tantangan-tantangan yang membuat imannya semakin teguh dengan penuh ketaatan kepada Tuhan. Janji berkat yang diberikan Tuhan kepada Abraham tidaklah secara keseluruh langsung tergenapi dalam satu waktu bersamaan tetapi janji berkat Tuhan kepada Abraham, satu per satu terjadi dalam waktu yang berbeda namun selama penantian, janji pernyertaan dan perlidungan Allah kepada Abraham selalu tergenapi.

Janji Tuhan bahwa Abraham akan menjadi bangsa yang besar dan akan memasyurkan namanya yang dalam hal ini ialah keturunan, harus dinantikan oleh Abraham selama 10 tahun. Pada saat Tuhan memanggil Abraham, Sara isterinya, mandul. Namun Allah menjanjikan keturunan kepada Abraham. Sepuluh tahun penantian bukanlah waktu yang singkat untuk Abraham. Bahkan Abraham sempat kwatir dan takut karena tidak adanya keturunan baginya. Dalam kekwatirannya, Abraham berkata kepada Allah “... aku akan meninggal dengan tidak mempunyai anak ..." (Kej. 15:2). Namun melalui keadaan itu, Abraham mendapat peneguhan dari Tuhan yang menjaminnya supaya tak khawatir karena ia akan diberikan keturunan sebanyak bintang di langit (Kej. 15:5). Mendengar jaminan Tuhan itu, Abraham langsung percaya dan tindakan percayanya ini dipandang sebagai kebenaran. ${ }^{28}$ Abraham mendapatkan seorang anak laki-laki yang kemudian diberi nama Ishak. Abraham telah memiliki

\footnotetext{
${ }^{27}$ F.L. Bakker, Sejarah Kerajaan Allah 1 (Jakarta: Gunung Mulia, 2016), 97-99.

28 Yonky Karman, Bunga Rampai Teologi Perjanjian Lama: Dari Kanon Sampai Doa (Jakarta: Gunung Mulia, 2004), 140.
} 
keturunan dan Tuhan meneguhkan Abraham hingga sampai saat ini Abraham disebut sebagai "bapa segala orang percaya/beriman". Setelah mendapatkan Ishak sebagai harapan generasi penerusnya, tantangan iman tidak serta merta berakhir bagi Abraham. Suatu hal yang memiluhkan hati Abraham ketika Tuhan meminta Ishak untuk dijadikan korban persembahan bagiNya. Anak yang Tuhan janjikan, yang telah ditunggu begitu lama telah ada namun harus direlakan oleh Abraham karena Tuhan memintanya.. Hal ini merupakan ujian untuk iman dan ketaatan Abraham kepada Allah. Namun, pada akhirnya Abraham memilih untuk tetap taat pada Tuhan, meskipun Ishak, anak yang dikasihinya harus dipersembahkannya. Tuhan melihat ketaatan dan iman Abraham dalam menghadapi tantangan dan ujian yang diperhadapkan baginya. Seperti yang dikatakan oleh Bakker bahwa Iman adalah ketaatan, penyerahan diri seluruhnya kepada Allah dengan tidak menanyakan sebabnya, dengan tidak ada kesangsian, ${ }^{29}$ seperti itulah iman Abraham. Abraham pergi oleh karena Allah yang mengatakannya.

Semua tantangan yang dihadapi Abraham membuatnya kwatir, bimbang hingga harus mengorbankan anaknya karena ketaatan dan imannya kepada Tuhan. Namun dari semuanya itu, Allah menyatakan berkat-Nya atas Abraham. Semua tantangan dan pergumulan yang dialami oleh Abraham membawa berkat dalam hidupnya. Jadi berkat yang diterima oleh Abraham bukan hanya hal yang terlihat baik, tetapi dalam hal kesusahan dan pergumulan pun berkat Allah nyata bagi Abraham sebab perlindungan Tuhan selalu ada disepanjang perjalanan Abraham menuju kepada janji berkat Tuhan. Ini mematahkan pernyataan bahwa berkat adalah segala hal yang baik, yang mendatangkan sukacita dalam hidup. Berkat yang sesungguhnya adalah segala hal yang Tuhan nyatakan dalam hidup ini, entah itu kebaikan ataupun kesusahan (menurut pandangan duniawi) yang mendatangkan kebaikan bagi manusia. Meskipun dalam kesusahan atau pergumulan, penyertaan dan perlindungan Tuhan harusnya membuat manusia merasakan bahwa Tuhan selalu ada dalam kondisi apapun itu. Dan yang terpenting dari semuanya ialah iman dan kepercayaan penuh kepada Tuhan serta ketaatan dalam melakukan atau mengerjakan apa yang Tuhan kehendaki dalam hidup ini.

\section{Relevansi}

Berkat adalah suatu anugerah yang diberikan Tuhan kepada semua orang. ${ }^{30}$ Berkat itu juga dipandang sebagai kasih karunia atau kasih sayang Tuhan kepada umatNya. ${ }^{31}$ Dari pemahaman beberapa warga Jemaat Kollo tentang berkat, maka dapat ditarik satu pengertian bahwa berkat adalah pemberian, anugerah, karunia dari Tuhan yang menandakan kasih sayang Tuhan dalam kehidupan setiap orang. Lalu berkat itu dijabarkan dalam berbagai bentuk berkat, seperti kesehatan, keturunan, umur panjang,

\footnotetext{
${ }^{29}$ Bakker, Sejarah Kerajaan Allah 1, 100.

30 Wawancara dengan Bapak Marthen Massang, Bapak Y.S. Sampebua, Bapak Yohanis Moni, Ibu Yusmin Bangalino, dan Ibu Yulianti Patandianan pada tanggal 04,07 dan 08 Juni 2019.

31 Wawancara dengan Bapak Rape Tanggulungan, Cindi Patandianan, Upa', dan Yunita Tangke pada tanggal 04 dan 07 Juni 2019
} 
pekerjaan, harta benda, talenta, kepandaian, ketentraman, dan kedamaian. ${ }^{32}$ Tak terlintas dalam pikiran bahwa hal yang tidak menyenangkan seperti kesusahan adalah juga berkat dari Tuhan.

Dari kenyataan diatas, meskipun jarang kita temui, namun masih ada warga jemaat Kollo yang memiliki pemahaman yang berbeda. Ada beberapa warga jemaat Kollo yang mengatakan bahwa segala yang terjadi dalam hidup ini, duka ataupun suka adalah berkat dari Tuhan karena dibalik duka, Tuhan masih memberi kita nafas hidup dan memberi kita kekuatan untuk menghadapi hal itu. ${ }^{33}$ Semua yang terjadi dalam hidup adalah Tuhan yang mengatur dan mengendalikan. ${ }^{34}$ Melalui kesusahan dan penderitaan, Tuhan mau menyatakan ke-Maha Kuasaan-Nya dan kehendak-Nya dalam kehidupan manusia. ${ }^{35}$ Kesusahan dan penderitaan dapat membentuk kita menjadi pribadi yang kuat. ${ }^{36}$ Namun tak sedikit pula yang menyebutkan bahwa kesusahan, sakit penyakit, kegagalan, kehilangan sesuatu/seseorang, penderitaan, kemiskinan, bencana, dan hal buruk lainnya adalah suatu teguran dari Tuhan karena telah melakukan suatu hal yang tidak dikehendaki oleh Tuhan. ${ }^{37}$ Bahkan ada yang memberi penegasan bahwa hal itu bukan bagian dari berkat Tuhan melainkan suatu musibah yang terjadi yang membuat kita susah dan menderita ${ }^{38}$ dan hal itu adalah bentuk kemarahan Tuhan atas segala perbuatan buruk yang dilakukan oleh manusia karena setiap hal yang buruk terjadi dalam hidup ini pasti ada penyebabnya. ${ }^{39}$ Ada juga yang menyebutkan bahwa kesusahan itu merupakan kesalahan diri sendiri. Diri sendiri yang menyebabkan hal itu terjadi, seperti halnya kemiskinan disebabkan oleh diri sendiri yang tidak mau berusaha atau bekerja. ${ }^{40}$

Dari tafsiran dan teologi kejadian 12:1-3 diatas, telah dijelaskan bahwa berkat adalah segala hal yang Tuhan nyatakan dalam hidup ini, entah itu kebaikan maupun kesusahan (menurut pandangan duniawi). Tuhan adalah sumber segala berkat dalam hidup ini. Segala hal yang Tuhan nyatakan dalam hidup ini adalah baik adanya. Oleh sebab itu berkat dari Tuhan tidak selalu berbicara tentang hal yang baik-baik saja, tetapi terkadang lewat kesusahan, penderitaan, dan pergumulan hidup lainnya, berkat Tuhan selalu nyata bagi setiap orang yang memiliki iman dan ketaatan kepada Tuhan. Secara teologis, warga jemaat diberi pengajaran untuk selalu bersyukur dan menerima apapun yang Tuhan nyatakan dalam hidup ini, entah itu sesuatu yang baik maupun yang buruk. Jangan hanya mau menerima dan mensyukuri sesuatu yang baik saja, tetapi haruslah juga menerima dan mensyukuri sesuatu yang buruk sekalipun. Demikian yang dikatakan

32 Wawancara dengan Bapak Rape Tanggulungan, Bapak Y.S. Sampebua, Bapak Yohanis Moni,

Bapak Mathen Massang, Ibu Yulianti Patandianan, Ibu Agustina Lobo', Ibu Damaris Palumpun, Upa', Cindi

Patandianan, dan Yunita Tangke pada tanggal 04, 07 dan 08 Juni 2019

33 Wawancara dengan Bapak Y.S. Sampebua, Bapak Rape Tanggulungan, Upa', dan Cindy Patandianan pada tanggal 04, 07 dan 08 Juni 2019.

34 Wawancara dengan Bapak Rape Tanggulungan pada tanggal 07 Juni 2019.

35 Wawancara dengan Bapak Rape Tanggulungan pada tanggal 07 Juni 2019.

36 Wawancara dengan Cindy Patandianan pada tanggal 04 Juni 2019.

37 Wawancara dengan Bapak Marthen Massang, Bapak Yohanis Moni', Ibu Yusmin Bangalino, Ibu Yulianti Patandianan, Ibu Damaris Palumpun, Ibu Aagustina Lobo', Cindi Patandianan, Upa', dan Yunita Tangke pada tanggal 04,05, 07 dan 08 Juni 2019.

38 Wawancara dengan Bapak Marthen Massang dan Ibu Yusmin Bangalino pada tanggal 07 dan 08 Juni 2019.

39 Wawancara dengan Yunita Tangke pada tanggal 04 Juni 2019.

40 Wawancara dengan Bapak Yohanis Moni pada tanggal 07 Juni 2019. 
firman Tuhan dalam 1 Tesalonika 5:18 bahwa "mengucap syukurlah dalam segala hal, sebab itulah yang dikehendaki Allah didalam Kristus Yesus bagi kamu”. Seorang yang mampu bersyukur kepada Tuhan dalam segala hal memiliki iman dan ketaatan kepada Tuhan. Bersyukur sama halnya dengan tidak bersungut-sungut. Berkat Tuhan tidak hanya dinyatakan-Nya lewat hal-hal yang baik saja tetapi Tuhan juga menyatakan berkat-Nya dalam keadaan yang buruk sekalipun. Pdt. Remedi Peranginangin dalam bukunya mengatakan bahwa didalam Allah semua kengerian, kegentaran, kesesakan, kesengsaraan, dan kesusahan akan menjadi berita yang menyukacitakan, yang penuh dengan berkat Tuhan yang berkelimpahan. ${ }^{41}$ Artinya bahwa berkat Tuhan itu juga ada dalam hal yang membuat kita merasa susah dan menderita, bukan hanya ada dalam hal yang membuat hati senang saja.

Dari pemahaman beberapa informan di atas, maka dapat dikatakan bahwa sudah ada anggota Jemaat Kollo yang memiliki pemahaman yang cukup baik tentang berkat namun masih banyak anggota jemaat yang memiliki pemahaman bahwa berkat hanyalah hal yang baik-baik saja seperti kesehatan, keturunan, pekerjaan, umur panjang, harta benda, dan hal baik lainnya sedangkan hal yang tidak baik seperti kesusahan, penderitaan, bencana dan permugulan merupakan teguran dari Tuhan karena tidak melalukan kehendak-Nya. Pemahaman seperti ini membuat anggota jemaat merasa bersyukur dan menganggap diri diberkati oleh Tuhan ketika hal-hal yang baik seperti yang telah di kemukan diatas terjadi dalam hidup mereka, dan merasa tidak diberkati dan susah untuk bersyukur ketika menghadapi pergumulan atau masalah hidup karena menganggap itu bukan berkat dari Tuhan.

\section{Kesimpulan}

Dengan adanya pemahaman dimiliki oleh anggota jemaat seperti yang telah dipaparkan di atas, maka dalam praktiknya mereka akan berbuat seperti yang ada dalam pemahaman mereka. Pemahaman yang dimiliki akan menjadi hal yang sangat berpengaruhi dalam menyikapi hal-hal yang terjadi dalam hidup ini yang pada akhirnya juga sangat erat hubungannya dengan kehidupan iman anggota jemaat. Untuk itu, sangat perlu untuk membangun pemahaman yang baik tentang berkat dalam kalangan anggota jemaat. Pemahaman yang selama ini ada dan berkembang dalam kehidupan anggota jemaat tentang berkat, perlu diperbaharui demi terwujudnya suatu pemahanan yang benar tentang berkat yang menghasilkan iman yang sempurna kepada Tuhan.

Pemahaman yang dimiliki oleh anggota jemaat memberi kesadaran bahwa berkat selama ini dipandang sangat sempit. Namun setelah diketahui bahwa dalam rintangan, tantangan dan pergumulan yang dialami oleh Abraham, Tuhan menyatakan berkat-Nya.

Hal ini dapat dijadikan pengajaran kepada anggota jemaat yang akan mengubah pemahaman sebelumnya tentang berkat. Jemaat kollo perlu untuk memperhatikan pengajaran ini dan memahami dengan benar bahwa berkat Tuhan bukan hanya tentang hal-hal baik yang mendatangkan sukacita dan damai, melainkan berkat Tuhan juga ada dalam setiap pergumulan, kesusahan yang terjadi dalam hidup ini. Dengan

\section{h. 162}

${ }^{41}$ Remedi Peranginangin, Kesesakan Berubah Menjadi Berkat (Jakarta: BPK Gunung Mulia, 2017), 
memperhatikan dan mendalami proses kehidupan Abraham, maka dapat dilihat bahwa berkat yang diberikan Tuhan kepada Abraham tidak hanya ada dalam hal yang baik saja tetapi dalam hal kesusahan berkat Allah juga ada bagi Abraham. Diperlukan iman dan ketaatan kepada Tuhan untuk melihat berkat dalam kesusahan yang sedang terjadi dalam hidup ini. Abraham menjadi teladan yang baik bagi warga Jemaat Kollo dalam hal iman dan ketaatan hingga berkat yang diberikan Tuhan kepadanya.

\section{Daftar Pustaka}

Baker, D. L., S. M. Siahan, dan A. A. Sitompul. Pengantar Bahasa Ibrani. Jakarta: Gunung Mulia, 2010

Bakker, F.L. Sejarah Kerajaan Allah 1. Jakarta: Gunung Mulia, 2016.

Boeker, T.G.R. Bahasa Ibrani Jilid II. Batu: Literatur YPPII, 1993.

Enoh, I. Ketut. "Tinjauan Teologis Tentang Arti Berkat Dalam Kehidupan Orang Percaya”, Jaffray, Vol. 10, No. 1 Tahun 2012.

Henry, Matthew. Kitab Kejadian. Surabaya: Momentum, 2014.

H. Kelley, Page. Pengantar Tata Bahasa Ibrani Biblika. Surabaya: Momentum, 2013.

Karman, Yonky. Bunga Rampai: Teologi Perjanjian Lama. Jakarta: Gunung Mulia, 2004.

Lembaga Alkitab Indonesia - Penerbit Gandum Mas. The Full Life Study Bible: Alkitab Penuntun Hidup Berkelimpahan. Malang: Gandum Mas dan LAI, 2015.

Lempp, Walter. Tafsiran Alkitab: Kitab Kejadian 5:1-12:3. Jakarta: BPK Gunung Mulia, 2009.

Peranginangin, Remedi. Kesesakan Berubah Menjadi Berkat. Jakarta: Gunung Mulia, 2017.

Pfeiffer, Charles F. dan Everett F. Harrison (eds.). The Wyclife Bible Commentary: Tafsiran Alkitab Wyclife Volume 1, terjemahan Hananiel Nugroho, dkk. Malang: Gandum Mas, 2014.

Park, Abraham. Seri 1 Sejarah Penebusan: Silsilah Di Kitab Kejadian. Jakarta: Gramedia Widiasarana Indonesia, 2010.

Park, Abraham. Seri 2- Sejarah Penebusan: Pertemuan Yang Terlupakan; Perjanjian Suluh dan Penggenapannya. Jakarta: Gramedia Widiasarana Indonesia, 2011.

Simanjuntak, A., dkk. Tafsiran Alkitab Masa Kini 1. Jakarta: Yayasan Komunikasi Bina Kasih/OMF, 1998.

Widianto, Kasiati. "Sifat Panggilan Allah: Studi terhadap Panggilan Allah kepada Abraham dalam Kejadian 12:1-4". Kerusso, Vol. 2 No. 2. 2017. 